\title{
PENGARUH APLIKASI GEL THEOBROMINE TERHADAP KEKASARAN PERMUKAAN EMAIL GIGI DESIDUI PASCA DEMINERALISASI
}

Shoimah Alfa Makmur*, Rinaldi Budi Utomo*

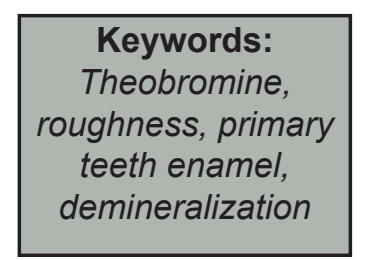

Keywords: Theobromine, roughness, primary teeth ename

\begin{abstract}
Background: Caries is common problem found in children. Caries prevalences increased mainly in developing countries such as Indonesia. Theobromine is an alkaloid compound in metilxantin group which can be found in the cocoa bean. Theobromine is believed to prevent caries by restoring the rough surface of email as the result of demineralisation. This research is aimed to analyze the effect of theobromine gel on the surface roughness of deciduous teeth after demineralization. Method: : It was laboratory experiments. Sample of research were 20 incisive cariesfree deciduous teeth. Samples divided into five groups of treatments (concentration of gel theobromine $1 \%, 2 \%, 3 \%, 4 \%$, and $5 \%$ ). Each group consists of 4 samples. All samples were demineralized with $37 \%$ phosphoric acid for 60 seconds. Samples were immersed in artificial saliva for 60 minutes in temperature $37^{\circ}$. Roughness examination before and after treatment was conducted using Surface Roughness Tester.

Result: This experiment showed that surface roughness is decreasing after treated by five different concentrations of theobromine. There is a significant difference compared to other treatments $(p<0,05)$.

Conclusion: Theobromine can be used as one of the caries preventive products. The effective concentration of gel theobromine to decrease surface roughness of teeth email is $5 \%$.
\end{abstract}

\section{PENDAHULUAN}

Karies merupakan salah satu masalah yang berkembang di masyarakat Indonesia. Karies seringkali ditemui pada anak-anak Tahap awal pembentukan karies dapat dicegah dengan terjadinya proses remineralisasi. Karies akan terjadi ketika proses demineralisasi lebih dominan. Apabila proses demineralisasi terjadi secara terus menerus berlanjut akan menyebabkan kehilangan sebagian dari prisma email dan akan terjadi porositas. Porositas ini menyebabkan kerusakan permukaan email sehingga email gigi menjadi kasar ${ }^{1}$. Jika $\mathrm{pH}$ di dalam rongga mulut menurun di bawah 5,5 akan mengakibatkan demineralisasi berkembang sehingga terjadi kerusakan pada struktur gigi $^{2}$.

Demineralisasi ini akan mengakibatkan inti prisma dan sebagian prisma bagian tepi hilang sehingga terjadi mikroporositas email. Hilangnya inti prisma email akan menyebabkan terjadinya ruang di tengah kristal hidroksiapatit. Akibatnya struktur prisma email menjadi tidak teratur dan kasar $^{3}$. Salah satu cara untuk meningkatkan kekerasan dan memperbaiki kekasaran permukaan gigi akibat proses demineralisasi email gigi adalah dengan mengembalikan strukturnya yang rusak dengan aplikasi bahan tambahan.

Pengembangan tanaman yang memiliki khasiat obat menjadi penting dan perlu dikembangkan karena diyakini bahwa obat yang berasal dari bahan alami relatif aman dan murah. Coklat atau Theobrema cacao sebagai sumber alami yang mengandung theobromine dapat dimanfaatkan dalam kedokteran gigi sebagai bahan pencegahan. Theobromine merupakan

*Departemen IImu Kedokteran Gigi Anak, Fakultas Kedokteran Gigi Universitas Gadjah Mada

Korespondensi: shoimah.alfa.drg@gmail.com 
senyawa alkaloid golongan metilxantina yang terdapat alami pada biji cokelat (Theobroma cacao $)^{4}$. Penelitian tentang theobromine (3,7-dimetilksantina) yang terdapat dalam ekstrak buah cokelat menemukan bahwa theobromine dapat digunakan sebagai bahan alami untuk mencegah karies ${ }^{5}$.

Efek positif dari theobromine ini dapat digunakan sebagai alternatif pengganti fluoride yang lebih aman sehingga diperlukan penelitian lebih lanjut mengenai konsentrasi efektif penggunaan theobromine pada gigi desidui yang telah terjadi demineralisasi. Penelitian ini bertujuan untuk mengetahui pengaruh berbagai konsentrasi gel theobromine terhadap kekasaran permukaan email gigi incisivus desidui setelah demineralisasi.

\section{METODE PENELITIAN}

Penelitian ini bersifat eksperimental. Sampel gigi yang digunakan merupakan gigi incisivus desidui utuh yang telah memiliki indikasi untuk dicabut. Pemilihan objek penelitian dilakukan secara simple random sampling. Objek penelitian terdiri dari 20 gigi incisivus desidui yang dibagi menjadi 5 kelompok perlakuan. Masing-masing kelompok perlakuan terdapat 4 objek penelitian. Semua kelompok dilakukan demineralisasi menggunakan asam fosfat $37 \%$ selama 60 detik sebelum dilakukan aplikasi topikal gel theobromine kemudian dilakukan pengujian kekasaran permukaan email.

Terdapat lima kelompok konsentrasi yang digunakan. Kelompok pertama diaplikasikan gel theobromine dengan konsentrasi $1 \%$. Kelompok kedua diberikan aplikasi topikal gel theobromine konsentrasi $2 \%$. Kelompok ketiga diberi aplikasi topikal gel theobromine konsentrasi 3\%. Kelompok keempat diberi ap- likasi topikal gel theobromine konsentrasi 4\% dan kelompok kelima diberi topikal aplikasi gel theobromine konsentrasi $5 \%$. Gel theobromine diaplikasikan dengan cara mengoleskan dipermukaan labial gigi incisivus desidui selama 4 menit menggunakan microbrush. Selanjutnya, objek diinkubasi selama 60 menit dalam saliva buatan kemudian dilakukan kembali pengujian kekasaran permukaan email gigi. Kekasaran permukaan email diukur dengan menggunakan Surface Roughness Tester.

Pengaruh gel theobromine terhadap perubahan kekasaran permukaan email pada kelompok konsentrasi 1\%, 2\%, 3\%, 4\% dan $5 \%$ dianalisis dengan uji Kruskal Wallis dilanjutkan dengan uji Mann Whitney

\section{HASIL PENELITIAN}

Hasil penelitian menunjukkan adanya pengaruh perubahan pada permukaan email gigi setelah aplikasi gel theobromine. Pada tabel 1 menunjukkan perbedaan antara rerata perubahan kekasaran permukaan email gigi setelah demineralisasi dan setelah paparan gel theobromine dengan konsentrasi $1 \%, 2 \%$, $3 \%, 4 \%$ dan $5 \%$.

Hasil uji Kruskal Wallis (tabel 2) menunjukkan ada pengaruh yang bermakna gel theobromine konsentrasi $1 \%$, 2\%, 3\%, 4\%, dan 5\% terhadap penurunan kekasaran permukaan email gigi $(p<0,05)$. Selanjutnya untuk mengetahui pasangan antar kelompok konsentrasi mana yang memiliki perbedaan yang bermakna dilakukan pengujian lebih lanjut dengan menggunakan uji Mann Whitney (tabel 3).

Hasil uji Mann Whitney menunjukkan penurunan kekasaran permukaan email tidak ada perbedaan bermakna antara kelompok konsentrasi gel theobromine $1 \%$ dengan konsentrasi gel theobromine $2 \%, 3 \%, 4 \%$; konsen- 
Tabel 1. Nilai rerata perubahan kekasaran permukaan email gigi incisivus desidui setelah demineralisasi dan setelah paparan gel theobromine

\begin{tabular}{|c|c|c|c|}
\hline \multirow[t]{2}{*}{$\begin{array}{l}\text { Konsentrasi } \\
(\%)\end{array}$} & \multicolumn{3}{|c|}{$\begin{array}{l}\text { Nilai Kekasaran Permukaan Email Gigi }(\mu \mathrm{m}) \\
\qquad(x \pm S D)\end{array}$} \\
\hline & $\begin{array}{c}\text { Setelah } \\
\text { Demineralisasi }\end{array}$ & $\begin{array}{c}\text { Setelah } \\
\text { Theobromine }\end{array}$ & Selisih \\
\hline $\begin{array}{l}1 \% \\
2 \% \\
3 \% \\
4 \% \\
5 \%\end{array}$ & $\begin{array}{l}2,1250 \pm 0,71910 \\
1,5975 \pm 0,42453 \\
1,5250 \pm 0,53326 \\
1,2575 \pm 0,17095 \\
1,3975 \pm 0.19551\end{array}$ & $\begin{array}{l}1,0575 \pm 0,12038 \\
0,9825 \pm 0,13623 \\
1,1175 \pm 0,38448 \\
0,8575 \pm 0,13598 \\
1,2075 \pm 0,18839\end{array}$ & $\begin{array}{l}1,0675 \pm 0,62249 \\
0,6150 \pm 0,30050 \\
0,4075 \pm 0,31170 \\
0,4000 \pm 0,27677 \\
0,1900 \pm 0,09201\end{array}$ \\
\hline
\end{tabular}

Tabel 2. Hasil uji Kruskal Wallis perubahan kekasaran permukaan gigi incisivus desidui setelah paparan gel theobromine

\begin{tabular}{cc}
\hline & $\begin{array}{c}\text { Kekasaran permukaan email } \\
\text { (sebelum-setelah }\end{array}$ \\
\hline $\mathrm{df}$ & 4 \\
$\mathrm{p}$ & 0,005 \\
\hline
\end{tabular}

Tabel 3. Hasil uji Mann Whitney perubahan kekasaran permukaan email gigi incisivus desidui setelah paparan gel theobromine antar kelompok konsentrasi

\begin{tabular}{cccccc}
\hline $\begin{array}{c}\text { Kelompok } \\
\text { Konsentrasi }\end{array}$ & $\mathbf{1 \%}$ & $\mathbf{2 \%}$ & $\mathbf{3} \%$ & $\mathbf{4 \%}$ & $\mathbf{5 \%}$ \\
\hline $1 \%$ & - & 0,248 & 0,083 & 0,110 & $0,021^{*}$ \\
$2 \%$ & - & - & 0,248 & 0,248 & $0,021^{*}$ \\
$3 \%$ & - & - & - & 1,000 & 0,149 \\
$4 \%$ & - & - & - & - & 0,191 \\
$5 \%$ & - & - & - & - & - \\
\hline
\end{tabular}

Keterangan:

p : probabilitas (tingkat kemaknaan) $p<0,05$

trasi gel theobromine $2 \%$ dengan konsentrasi gel theobromine 3\%, 4\%; konsentrasi gel theobromine $3 \%$ dengan konsentrasi gel theobromine 4\%, 5\%; dan konsentrasi gel theobromine $4 \%$ dengan konsentrasi gel theobromine $5 \%$. Namun penurunan kekasaran permukaan email gigi terdapat perbedaan bermakna pada kelompok konsentrasi 5\% dibandingkan dengan kelompok konsentrasi gel theobromine lainnya.

\section{DISKUSI}

Demineralisasi pada permukaan email akibat pengaruh asam akan menyebabkan terjadinya mikroporositas dengan kedalaman mencapai $50 \mu \mathrm{m}^{6}$. Demineralisasi oleh etsa asam fosfat $37 \%$ selama 60 detik ini akan mengakibatkan inti prisma dan sebagian prisma bagian tepi hilang sehingga terjadi mikroporusitas email. Hilangnya inti prisma email akan menyebabkan terjadinya ruang di ten- 
gah kristal hidroksiapatit yang mengakibatkan struktur prisma email menjadi tidak teratur dan kasar $^{3}$.

Hasil penelitian menunjukkan bahwa konsentrasi topikal aplikasi gel theobromine $1 \%$, $2 \%$, 3\%, $4 \%$, dan $5 \%$ memberikan perbedaan bermakna terhadap kekasaran permukaan gigi. Hal ini sesuai dengan penelitian Amaechi dkk., (2013), bahwa kandungan ekstrak biji kakao, salah satunya adalah theobromine mampu meningkatkan resistensi email gigi pada permukaan email setelah terpapar oleh zat asam ${ }^{6}$.

Pada penelitian ini dapat disimpulkan bahwa konsentrasi gel theobromine $5 \%$ menunjukkan penurunan kekasaran permukaan email dan peningkatan kekerasan email yang paling efektif. Proses remineralisasi dengan penambahan bahan theobromine dapat membantu pengendapan ion fosfat dan kalsium pada permukaan email. Hal tersebut menunjukkan bahwa theobromine dapat meningkatkan kepadatan kristal dan menyebabkan porositas permukaan email gigi berkurang sehingga permukaan email gigi lebih tahan terhadap abrasi karena asam maupun mekanis ${ }^{7}$.

Pada demineralisasi yang dilakukan dengan asam fosfat, porositas pada lapisan prisma email meningkat. Terbukanya prisma enamel (porositas) akan dapat meningkatkan kontak dengan penetrasi gel theobromine pada permukaan email gigi yang menyebabkan peningkatan kristal apatit. Pengendapan ion pada prisma email tersebut akan sulit dilepas karena bentuk prisma yang sempit, serta adanya adhesi polar yang lebih baik. Akibatnya, diperlukan kekuatan yang lebih besar untuk memisahkan semua atom yang menyusun kristal apatit.

Hal ini menyebabkan porositas tertutup sehingga permukaan menjadi lebih halus dan akan meningkatkan kepadatan kristal apatit sehingga terlihat dengan adanya kekasaran permukaan email menurun dan membuatnya sulit untuk dihancurkan. Dalam penelitian ini terlihat dari penurunan kekasaran permukaan email gigi.

\section{KESIMPULAN}

Berdasarkan hasil penelitian mengenai pengaruh konsentrasi paparan gel theobromine terhadap kekasaran permukaan email gigi desidui setelah demineralisasi, dapat disimpulkan bahwa konsentrasi gel theobromine $5 \%$ paling efektif dalam menurunkan kekasaran permukaan email gigi desidui setelah terjadi demineralisasi.

\section{DAFTAR PUSTAKA}

1. Fajerskov, O., Kidd, E.A.M., 2003, Dental Caries Diseases and Its Clinical Management, Blackwell Munksgaard.

2. Nasution, A.I., 2016, Jaringan Keras Gigi - Aspek Mikroskopis dan Aplikasi Reset, Syiah Kuala University Press, Banda Aceh.

3. Sintawati, J., Soemartino, S.H., Suharsini, M., 2008, Pengaruh Durasi Aplikasi Asam Fosfat $37 \%$ terhadap Kekuatan Geser Restorasi Resin Komposit pada Enamel Gigi Tetap. Indonesian Journal of Dentistry, 15(2): 97-103 (Sadeghpour, 2007)

4. Syafira, G., Permatasari, R., Wardani, N., 2012, Theobromine Effect on Enamel Surface Microhardness: In Vitro, Dent Indonesia, 19(2):32-6.

5. Hicks, J., Garcia-Godoy, F., Flaitz, C., 2005, Biological Factors in Dental Caries Enamel Structure and the Caries Proccess in the Dynamic Proccess of Demineralization and Remineralization (Part 2), J Clin Pediatr Dent., 29(2): 119-124.

6. Amaechi, B.T., Porteous, N., Ramalingan, K., Mensikai, P.K., Cahuana, V.R.A., Sadeghpour, A., Nakamoto, T., 2013, Remineralization of Artificial Enamel Lesion by theobromine, Caries Res, 47:399-405.

7. Mahardika A., Noerdin, A., Eriwati, Y.K., 2017, The Effect of Brushing on Human Enamel Surface Roughness after NaF Gel and Theobromine Gel Exposure, The 1st Physics and Technologies in Medicine and Dentistry Symposium, Journal of Physics: Conf. Series: 884 